\title{
Age-specific cancer survival in Estonia: recent trends and data quality
}

This article was published in the following Dove Press journal:

Clinical Epidemiology

29 July 2015

Number of times this article has been viewed

\section{Kaire Innos' \\ Katrin Lang ${ }^{2}$ \\ Kersti Pärna ${ }^{2}$ \\ Tiiu Aareleid'}

'Department of Epidemiology and Biostatistics, National Institute for Health Development, Tallinn, Estonia; ${ }^{2}$ Department of Public Health, University of Tartu, Tartu, Estonia
Correspondence: Kaire Innos Department of Epidemiology and Biostatistics, National Institute for Health Development, Hiiu 42,

II619 Tallinn, Estonia

$\mathrm{Tel}+3726593941$

Fax +372 659390

Email kaire.innos@tai.ee
Background: A number of population-based studies have demonstrated lower cancer survival in elderly patients than among middle-aged or younger patients. Also, data quality in cancer registries has been shown to be associated with age. The objective of this study was to examine the recent age-specific cancer survival trends and age-specific quality of cancer data in Estonia.

Methods: Using Estonian Cancer Registry data, we calculated relative survival ratios (RSRs) for eight common cancers in Estonia in 1995-1999 (cohort method) and 2005-2009 (period method) for four major age groups (15-54, 55-64, 65-74, and 75-84 years at diagnosis). The main data quality indicators were calculated, and the age-specific effect of missing death certificate initiated (DCI) cases on survival was estimated comparing 5-year RSRs computed from the complete data set with those from data set without DCI cases.

Results: We observed overall rise in 5-year RSR for all eight cancers over the study period, with a considerable variation by age, with the lowest survival among the oldest patients. The widest age gradient in 5-year RSR was seen for bladder cancer (20\% units in 2005-2009), followed by cancers of lung (16\% units), kidney (15\% units), breast and prostate (13\% units), stomach and rectum ( $11 \%$ units), and colon ( $5 \%$ units). All data quality indicators, including proportion of cases with unknown stage showed a similar age-related pattern with the lowest quality in the oldest age group. The effect of missing DCI cases on survival estimates increased by age and was around 3\% units for prostate and kidney cancers among the oldest patients.

Conclusion: Young or middle-aged patients in Estonia experienced larger survival gain since the late 1990s than elderly patients. Decreasing quality of cancer registry data along with increasing patient age suggests less thorough clinical investigations in older age groups.

Keywords: cancer registry, population-based, relative survival, age differences, data quality

\section{Introduction}

In all Western countries, the aging population gives rise to an increasing cancer burden. The increase in absolute number and proportion of elderly patients raises new challenges for their clinical management and monitoring outcomes in cancer care. According to the results of population-based survival studies in Europe and USA, elderly patients have profited less from recent survival increases than younger patients. ${ }^{1,2}$ In Estonia, a recent paper demonstrated that breast cancer survival was significantly worse for elderly patients, particularly for patients with advanced stages of the disease. ${ }^{3}$ Completeness and quality of cancer registry data are important prerequisites for obtaining valid population-based survival estimates. ${ }^{4,5}$ There is evidence of variation in data quality indicators by age. For example, higher proportion of death certificate only (DCO) cases as well as cases with unavailable stage and grade data have 
been observed among elderly breast and colorectal cancer patients compared to their younger counterparts. ${ }^{6}$

Our study is based on the Estonian Cancer Registry (ECR), which is population-based, covers the whole country (population, 1.34 million according to the 2011 census) and has data since $1968 .^{7}$ The established practices of the ECR were interrupted by the 2003 Personal Data Protection Act that prohibited the linkage of the ECR data to the Cause of Death Registry, ${ }^{8}$ and thus, prevented the use of death certificates as an additional source for case ascertainment, concerning cases diagnosed in 2001-2007. The legal problem was solved with the 2007 Act and the ECR was thereafter supplemented with previously missing incident cases. A recent analysis demonstrated that the effect of excluding death certificate initiated (DCI) cases on overall survival estimates was small. ${ }^{9}$ However, it is not known whether the effect is similar across all age groups. Our hypothesis is that the proportion of DCI cases is likely to increase with age, and thus, the effect of missing DCI cases may be larger among elderly patients and this in turn may have implications for the interpretation of age-specific survival estimates.

Thus, the objective of this study was to examine the recent trends in age-specific survival for common cancers in Estonia, with special emphasis on estimating age-specific data quality and the effect of missing DCI cases on relative survival estimates.

\section{Materials and methods}

The ECR provided data on all adult cases (diagnosed in patients age 15 years and older) of eight common cancers in 1995-2008, regardless of cancer sequence: stomach (ICD-10 code $\mathrm{C} 16)$, colon (C18), rectum, rectosigmoid junction, anus (C19-C21), lung, trachea (C33-C34), breast (C50), prostate (C61), kidney, renal pelvis (C64-C65), bladder, ureter, other urinary organs (C66-C68). The patients were categorized into four age groups based on age at diagnosis as 15-54, 55-64, 65-74, and 75-84 years. We excluded patients diagnosed at age 85 years and older from the analyses due to small numbers and statistical instability. For prostate and bladder cancer, the two youngest age groups were collapsed due to small numbers in age group 15-54. The following quality indicators were calculated: percentage of microscopically verified cases $(\% \mathrm{MV})$, percentage of cases based on death certificate only $(\% \mathrm{DCO})$, and percentage of cases diagnosed at autopsy (\%Autopsy). Percentage of death certificate initiated cases $(\% \mathrm{DCI})$ is presented among those diagnosed in 2001-2008 and eligible for survival analysis because all cases ascertained as DCI were not flagged as such prior to 2001.
Survival analysis did not include autopsy and DCO cases $(n=1,657)$. The patients were followed up for vital status until December 31, 2009 using linkage with the Population Registry. In case of death or emigration, the respective date was ascertained. Routine linkage of ECR data to the population registry is based on unique personal identification numbers, introduced in Estonia in 1992, ${ }^{10}$ and is therefore regarded sufficiently complete. Linkage to the population registry was not affected by the legal problems described above.

The extent of disease was grouped into four categories based on the information reported to the cancer registry as: 1) localized, 2) local/regional spread (regional lymph nodes or adjacent tissues), 3) distant (distant metastases), and 4) unknown extent.

The significance of the difference between proportions was tested using chi-square test. Relative survival was calculated as the ratio of the observed survival of cancer patients and the expected survival of the underlying general population. The latter was calculated according to the Ederer II method ${ }^{11}$ using national life tables for Estonian population stratified by age, sex, and calendar year. Period method was used for obtaining the most recent relative survival ratios (RSRs) with a period window 2005-2009. ${ }^{12}$ As follow-up was more up-to-date than the registration of incident cases (cases diagnosed in 2009 were not yet available for analysis), a modification of period analysis, called hybrid analysis was used. ${ }^{13}$ To assess recent changes in survival, period estimates of 5-year survival for 2005-2009 were compared to 5-year survival estimates derived by cohort analysis for patients diagnosed in 1995-1999. Survival analysis was performed for all stages combined.

In order to measure the effect of missing DCI cases on survival estimates in age groups, we compared crude 5-year RSRs for 2005-2009 computed from the complete data set (DCI cases included) with those from data set without DCI cases and also calculated their difference RSR $_{\text {DCI-excluded }}-$ $\left.\mathrm{RSR}_{\mathrm{DCI} \text {-included }}\right)$ and relative difference as a percentage of the "true" (DCI cases included) estimates $\left(\left(\mathrm{RSR}_{\text {DCI-excluded }}\right.\right.$ ' $\left.\left.\mathrm{RSR}_{\text {DCI-excluded }}\right)-1\right) \times 100$. The two youngest age groups were collapsed for this analysis for all sites.

The International Cancer Survival Standards ${ }^{14}$ were used for age-standardizing overall RSRs. All calculations were conducted with Stata 12.1 (StataCorp LP, College Station, TX, USA); survival analysis was performed using the strs module. ${ }^{15}$

The study protocol was approved by the Tallinn Medical Research Ethics Committee. 


\section{Results}

The total number of cases by eight cancer sites, mean age at diagnosis, and age distribution is presented in Table 1. The age group $65-74$ years comprised $35 \%-45 \%$ of all cancer sites but breast (24\%), for which one-third of the patients were diagnosed at less than 55 years of age. Patients who are 85 years or older at diagnosis $(2 \%-7 \%$ by site) were excluded from further analyses $(n=2,090)$. The age-related pattern was generally similar for all the data quality indicators shown in Table 2; \%MV decreased with age and dropped considerably for the $75-84$ years age group and $\% \mathrm{DCO}$ was the highest in the oldest age group. The largest \%Autopsy was seen in kidney cancer - over 3\% in all age groups, and $7 \%$ in the $75-84$ years age group. As shown in Table 3, the percentage of cases with unknown extent of disease was by far the largest in the 75-84 years age group. The proportion of cancers diagnosed at localized stage was generally stable over the age span, but decreased notably with age for prostate and kidney cancers.

In 2005-2009, the 1-year RSRs differed significantly between the youngest and oldest age groups for all sites but kidney (Table 4). The largest age gradient was seen for rectal cancer ( $23 \%$ units), followed by lung cancer ( $21 \%$ units), while the smallest age gradient ( $8 \%$ units) was seen for breast and prostate cancers. In the 5-year RSRs, the largest age gradient was seen for bladder cancer ( $20 \%$ units), while it was also significant for kidney, lung, breast, prostate, and stomach cancer.

The changes in the 5-year RSR over time are shown in Figure 1. Major survival improvement for stomach cancer was seen only among patients aged $65-74$ years, leaving the age gradient unchanged. For colon cancer, survival increase was confined to the 55-64 years age group, and the 5-year RSR even declined in the youngest age group, resulting in reduced age gradient (from $13 \%$ units to $5 \%$ units). There was an indication of considerable survival improvement for rectal cancer in all age groups, particularly among the elderly (14\% unit increase in the 75-84 years age group) as well as in the 55-64 years age group (statistically significant 13\% unit increase). In lung cancer, the age gradient in survival widened from $3 \%$ units to $16 \%$ units as the 5 -year RSR for the youngest age group doubled over the study period (statistically significant). Breast cancer survival increased significantly in all age groups but the oldest and, as a consequence, the age difference increased from $6 \%$ units to $13 \%$ units. Major statistically significant survival increases were seen in all age groups of prostate cancer patients. Despite the $16 \%$ unit survival increase in the oldest age group over the study period, the age gradient reached $13 \%$ units in the most recent period. For kidney cancer, the largest and significant survival increase was seen in the 65-74 years at diagnosis age group; the age gradient, however, remained wide. A steep age gradient was also observed for bladder cancer during both periods.

Among the cases eligible for survival analysis, the $\% \mathrm{DCI}$ was the highest among the oldest patients for all sites except breast (Table 5). The comparison of 5-year RSRs between DCI-included and DCI-excluded data sets showed that both the absolute and relative difference generally increased with age. The absolute difference in the 5-year RSRs was below $2 \%$ units in patients younger than 75 years of age for all sites, but in the 75-84 years age group, the gap exceeded $2 \%$ units for rectal, kidney and bladder cancer and 3\% units for prostate cancer. Relative difference (\% overestimation) was largest for cancers with the poorest prognosis and reached $19 \%$ for lung cancer in the oldest age group.

\section{Discussion}

In this population-based study of eight common cancers, we found overall rise in relative survival with considerable variation across age groups, with the lowest survival rates amongst the oldest patients ( $75-84$ years). The widest age gradient was

Table I Total number of adult incident cases of eight common cancers, mean age (years) and age distribution at diagnosis, Estonia 1995-2008

\begin{tabular}{|c|c|c|c|c|c|c|c|}
\hline \multirow[t]{2}{*}{ Cancer site } & \multirow[t]{2}{*}{ Number of cases } & \multirow[t]{2}{*}{ Mean age } & \multicolumn{5}{|c|}{ Age distribution at diagnosis, number (\%) } \\
\hline & & & I5-54 years & $55-64$ years & $65-74$ years & $75-84$ years & $85+$ years \\
\hline Stomach & 6,334 & 67 & I,032 (16) & I,400 (22) & $2,218(35)$ & $\mathrm{I}, 375(22)$ & $309(5)$ \\
\hline Colon & 5,789 & 70 & $570(10)$ & $\mathrm{I}, 126(19)$ & $2,166(37)$ & $\mathrm{I}, 567(27)$ & $360(6)$ \\
\hline Rectum & 3,807 & 69 & $409(11)$ & $830(22)$ & $\mathrm{I}, 406(37)$ & $938(25)$ & $224(6)$ \\
\hline Lung & 10,733 & 67 & I,322 (I2) & $2,997(28)$ & $4,24 \mid(40)$ & I,937 (I8) & $236(2)$ \\
\hline Breast (female) & 8,176 & 61 & $2,755(34)$ & $2,065(25)$ & $\mathrm{I}, 955(24)$ & $\mathrm{I}, 094(\mathrm{I})$ & $287(4)$ \\
\hline Prostate & 7,388 & 71 & $233(3)$ & I,42। (19) & $3,348(45)$ & $2,029(27)$ & $357(5)$ \\
\hline Kidney & $3,57 \mid$ & 65 & 664 (19) & $948(27)$ & $\mathrm{I}, 233(35)$ & $619(17)$ & $107(3)$ \\
\hline Bladder & 2,938 & 70 & 274 (9) & 565 (19) & $\mathrm{I}, 097$ (37) & 792 (27) & $210(7)$ \\
\hline
\end{tabular}


Table 2 Quality indicators for eight common cancers by age at diagnosis (years), Estonia 1995-2008

\begin{tabular}{|c|c|c|c|c|c|c|c|c|c|c|c|c|}
\hline \multirow[t]{2}{*}{ Cancer site } & \multicolumn{4}{|l|}{$\% M V$} & \multicolumn{4}{|c|}{ \%DCO } & \multicolumn{4}{|c|}{ \%Autopsy } \\
\hline & $\begin{array}{l}15-54 \\
\text { years }\end{array}$ & $\begin{array}{l}55-64 \\
\text { years }\end{array}$ & $\begin{array}{l}65-74 \\
\text { years }\end{array}$ & $\begin{array}{l}75-84 \\
\text { years }\end{array}$ & $\begin{array}{l}15-54 \\
\text { years }\end{array}$ & $\begin{array}{l}55-64 \\
\text { years }\end{array}$ & $\begin{array}{l}65-74 \\
\text { years }\end{array}$ & $\begin{array}{l}75-84 \\
\text { years }\end{array}$ & $\begin{array}{l}15-54 \\
\text { years }\end{array}$ & $\begin{array}{l}55-64 \\
\text { years }\end{array}$ & $\begin{array}{l}65-74 \\
\text { years }\end{array}$ & $\begin{array}{l}75-84 \\
\text { years }\end{array}$ \\
\hline Stomach & 95.3 & 92.6 & 90.8 & 83.6 & 1.0 & 1.5 & $\mathrm{I} .4$ & 2.7 & 1.3 & 1.8 & 1.5 & 2.0 \\
\hline Colon & 96.7 & 93.8 & 92.5 & 85.0 & 0.2 & 0.6 & 1.2 & 1.8 & I.I & 0.6 & $\mathrm{I} .4$ & 2.1 \\
\hline Rectum & 97.6 & 95.2 & 93.7 & 88.3 & 0.7 & 0.5 & I.I & 2.1 & 0.5 & 0.2 & 0.8 & 1.0 \\
\hline Lung & 86.2 & 80.9 & 72.7 & 51.6 & 1.6 & 2.5 & 3.3 & 6.1 & 2.3 & 3.1 & 3.1 & 3.7 \\
\hline Breast (female) & 98.0 & 96.9 & 94.1 & 89.1 & 0.3 & 0.5 & 1.0 & 1.9 & 0.1 & 0.3 & 0.2 & 0.3 \\
\hline Prostate $^{\mathrm{a}}$ & $-^{\mathrm{a}}$ & 94.9 & 92.9 & 85.1 & $--^{\mathrm{a}}$ & 0.4 & 1.0 & 2.7 & $-^{\mathrm{a}}$ & 2.6 & 2.1 & 2.3 \\
\hline Kidney & 89.3 & 86.2 & 82.3 & 66.7 & 0.8 & 1.0 & 1.3 & 2.4 & 3.5 & 3.2 & 3.3 & 7.0 \\
\hline Bladder $^{\mathrm{a}}$ & $-^{\mathrm{a}}$ & 96.5 & 95.1 & 91.0 & $--^{\mathrm{a}}$ & 0.7 & 1.0 & 2.3 & $-^{\mathrm{a}}$ & 0.8 & 0.7 & 1.9 \\
\hline
\end{tabular}

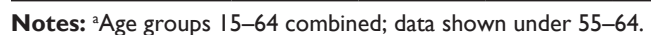

Abbreviations: \%MV, percentage of microscopically verified cases; \%DCO, percentage of cases based on death certificate only; \%Autopsy, percentage of cases diagnosed at autopsy.

seen for bladder cancer, without any particular changes over the study period. The age difference remained large for cancers of kidney and stomach, and decreased somewhat for colon and rectal cancer. Major changes occurred for cancers of lung, breast, and prostate as the age gradient widened considerably.
When interpreting the age gradient, it should be kept in mind that for most sites the survival of patients in the 15-54 years age group is lower in Estonia compared with the more affluent European countries. ${ }^{16,17}$ Hence, in international context the survival of elderly patients is particularly poor.

Table 3 Stage distribution of cases of eight common cancers (age I5-84 years) eligible for survival analysis by age at diagnosis (years), Estonia 1995-2008

\begin{tabular}{|c|c|c|c|c|c|c|c|}
\hline \multirow[t]{2}{*}{ Cancer site } & \multirow[t]{2}{*}{ Stage } & \multirow{2}{*}{$\frac{\text { Total }}{\%}$} & \multirow{2}{*}{$\begin{array}{l}\text { I5-54 years } \\
\%\end{array}$} & \multirow{2}{*}{$\begin{array}{l}\text { 55-64 years } \\
\%\end{array}$} & \multirow{2}{*}{$\begin{array}{l}\text { 65-74 years } \\
\%\end{array}$} & \multirow{2}{*}{$\begin{array}{l}75-84 \text { years } \\
\%\end{array}$} & \multirow[t]{2}{*}{$P$-value ${ }^{a}$} \\
\hline & & & & & & & \\
\hline \multirow[t]{4}{*}{ Stomach } & Localized & 24 & 23 & 24 & 23 & 25 & $<0.0005$ \\
\hline & Local/regional spread & 25 & 26 & 24 & 26 & 23 & \\
\hline & Distant & 42 & 46 & 46 & 43 & 38 & \\
\hline & Unknown & 9 & 5 & 6 & 8 & 13 & \\
\hline \multirow[t]{4}{*}{ Colon } & Localized & 40 & 35 & 38 & 43 & 39 & $<0.0005$ \\
\hline & Local/regional spread & 26 & 31 & 27 & 25 & 26 & \\
\hline & Distant & 29 & 32 & 32 & 28 & 28 & \\
\hline & Unknown & 4 & 2 & 3 & 4 & 7 & \\
\hline \multirow[t]{4}{*}{ Rectum } & Localized & 41 & 37 & 43 & 44 & 38 & $<0.0005$ \\
\hline & Local/regional spread & 29 & 33 & 28 & 30 & 29 & \\
\hline & Distant & 25 & 28 & 27 & 23 & 24 & \\
\hline & Unknown & 5 & 2 & 2 & 3 & 9 & \\
\hline \multirow[t]{4}{*}{ Lung } & Localized & 16 & 14 & 16 & 16 & 18 & $<0.0005$ \\
\hline & Local/regional spread & 37 & 41 & 39 & 38 & 32 & \\
\hline & Distant & 38 & 40 & 40 & 38 & 35 & \\
\hline & Unknown & 8 & 5 & 5 & 8 & 15 & \\
\hline \multirow[t]{4}{*}{ Breast (female) } & Localized & 42 & 43 & 43 & 40 & 42 & $<0.0005$ \\
\hline & Local/regional spread & 46 & 48 & 45 & 44 & 43 & \\
\hline & Distant & 9 & 6 & 9 & 12 & 9 & \\
\hline & Unknown & 3 & 3 & 3 & 4 & 6 & \\
\hline \multirow[t]{4}{*}{ Prostate $^{b}$} & Localized & 60 & $-\mathrm{b}$ & 64 & 61 & 55 & $<0.0005$ \\
\hline & Local/regional spread & 14 & $-^{\mathrm{b}}$ & 13 & 15 & 15 & \\
\hline & Distant & 15 & $-^{\mathrm{b}}$ & 16 & 14 & 13 & \\
\hline & Unknown & 11 & $-^{\mathrm{b}}$ & 7 & 10 & 17 & \\
\hline \multirow[t]{4}{*}{ Kidney } & Localized & 59 & 63 & 61 & 58 & 52 & $<0.0005$ \\
\hline & Local/regional spread & 13 & 10 & 13 & 12 & 16 & \\
\hline & Distant & 24 & 25 & 23 & 26 & 23 & \\
\hline & Unknown & 4 & 2 & 3 & 4 & 9 & \\
\hline \multirow[t]{4}{*}{ Bladder ${ }^{b}$} & Localized & 76 & $-{ }^{\mathrm{b}}$ & 78 & 76 & 74 & 0.067 \\
\hline & Local/regional spread & 12 & $--^{\mathrm{b}}$ & 13 & 12 & 12 & \\
\hline & Distant & 6 & $-^{\mathrm{b}}$ & 5 & 6 & 6 & \\
\hline & Unknown & 6 & $-^{\mathrm{b}}$ & 4 & 6 & 8 & \\
\hline
\end{tabular}

Notes: a Chi-square test; bage groups 15-64 combined; data shown under 55-64. 
Table 4 The I-year and 5-year relative survival ratios (\%) for eight common cancers by age at diagnosis (years), Estonia 2005-2009

\begin{tabular}{|c|c|c|c|c|c|c|c|c|c|c|c|c|}
\hline \multirow[t]{2}{*}{ Cancer site } & \multicolumn{2}{|c|}{$\begin{array}{l}\text { I5-84 (age- } \\
\text { adjusted) }\end{array}$} & \multicolumn{2}{|c|}{ I5-54 years } & \multicolumn{2}{|c|}{ 55-64 years } & \multicolumn{2}{|c|}{$65-74$ years } & \multicolumn{2}{|c|}{$75-84$ years } & \multirow[t]{2}{*}{$\begin{array}{l}\text { Age gradient } \\
\text { I-year RSR }\end{array}$} & \multirow[t]{2}{*}{$\begin{array}{l}\text { Age gradient } \\
\text { 5-year RSR }\end{array}$} \\
\hline & $\begin{array}{l}\text { I-year } \\
\text { RSR }\end{array}$ & $\begin{array}{l}\text { 5-year } \\
\text { RSR }\end{array}$ & $\begin{array}{l}\text { I-year } \\
\text { RSR }\end{array}$ & $\begin{array}{l}\text { 5-year } \\
\text { RSR }\end{array}$ & $\begin{array}{l}\text { I-year } \\
\text { RSR }\end{array}$ & $\begin{array}{l}\text { 5-year } \\
\text { RSR }\end{array}$ & $\begin{array}{l}\text { I-year } \\
\text { RSR }\end{array}$ & $\begin{array}{l}\text { 5-year } \\
\text { RSR }\end{array}$ & $\begin{array}{l}\text { I-year } \\
\text { RSR }\end{array}$ & $\begin{array}{l}\text { 5-year } \\
\text { RSR }\end{array}$ & & \\
\hline Stomach & 41 & 22 & 48 & 26 & 49 & 27 & 42 & 24 & 29 & 15 & $19^{b}$ & $1 \mathrm{I}^{\mathrm{b}}$ \\
\hline Colon & 71 & 51 & 79 & 51 & 75 & 55 & 73 & 53 & 60 & 46 & $19^{\mathrm{b}}$ & 5 \\
\hline Rectum & 73 & 50 & 84 & 52 & 77 & 57 & 74 & 51 & 61 & 41 & $23^{b}$ & 11 \\
\hline Lung & 30 & 11 & 41 & 21 & 35 & 12 & 29 & 10 & 20 & 5 & $21^{b}$ & $16^{b}$ \\
\hline Breast (female) & 92 & 74 & 96 & 80 & 94 & 78 & 90 & 73 & 88 & 67 & $8^{\mathrm{b}}$ & $13^{b}$ \\
\hline Prostate $^{c}$ & 93 & 78 & $-c^{c}$ & $-^{c}$ & 95 & 82 & 93 & 80 & 87 & 69 & $8^{b}$ & $13^{b}$ \\
\hline Kidney & 75 & 61 & 82 & 68 & 72 & 63 & 73 & 61 & 72 & 53 & 10 & $15^{\mathrm{b}}$ \\
\hline Bladder ${ }^{c}$ & 81 & 64 & $c^{c}$ & $c^{c}$ & 89 & 73 & 77 & 60 & 71 & 53 & $18^{b}$ & $20^{\mathrm{b}}$ \\
\hline
\end{tabular}

Notes: a Difference between the RSR of the youngest and oldest age groups; 'significant difference at the 0.05 level; 'age groups I5-64 combined; data shown under 55-64. Abbreviation: RSR, relative survival ratio.

The use of population-based data, collected uniformly over the study period, and the application of period analysis to provide up-to-date survival estimates were the major strengths of this study. On the other hand, small sample sizes for some cancers and/or age groups may have caused large random fluctuations in survival rates, and these results should be interpreted with caution.

We found that age was strongly associated with the quality of available patient data. The $\% \mathrm{MV}$ decreased consistently with age and was particularly low for lung and kidney cancer in the 75-84 years age group. This may be associated with elderly patients being less likely to undergo surgery ${ }^{18,19}$ or to receive standard diagnostic workup, including biopsy. ${ }^{20}$
The finding of lower histological confirmation among elderly patients was reported for a variety of cancers among Dutch patients. ${ }^{21}$ Likewise, we found higher proportion of cases with unknown stage data among the elderly, which again may be explained by insufficient diagnostic investigations. ${ }^{6,22}$

The chances of cancer cases being DCI or DCO increased with age in our study. A similar relation between age and $\% \mathrm{DCO}$ was seen for breast and colorectal cancer in the UK. ${ }^{6}$ This may be an indication of age-related incomplete clinical reporting of cancer cases, particularly for those dying soon after diagnosis. DCI cases often have short survival times, ${ }^{23}$ and if trace-back fails, then their exclusion from survival analysis as DCO cases leads to an overestimation

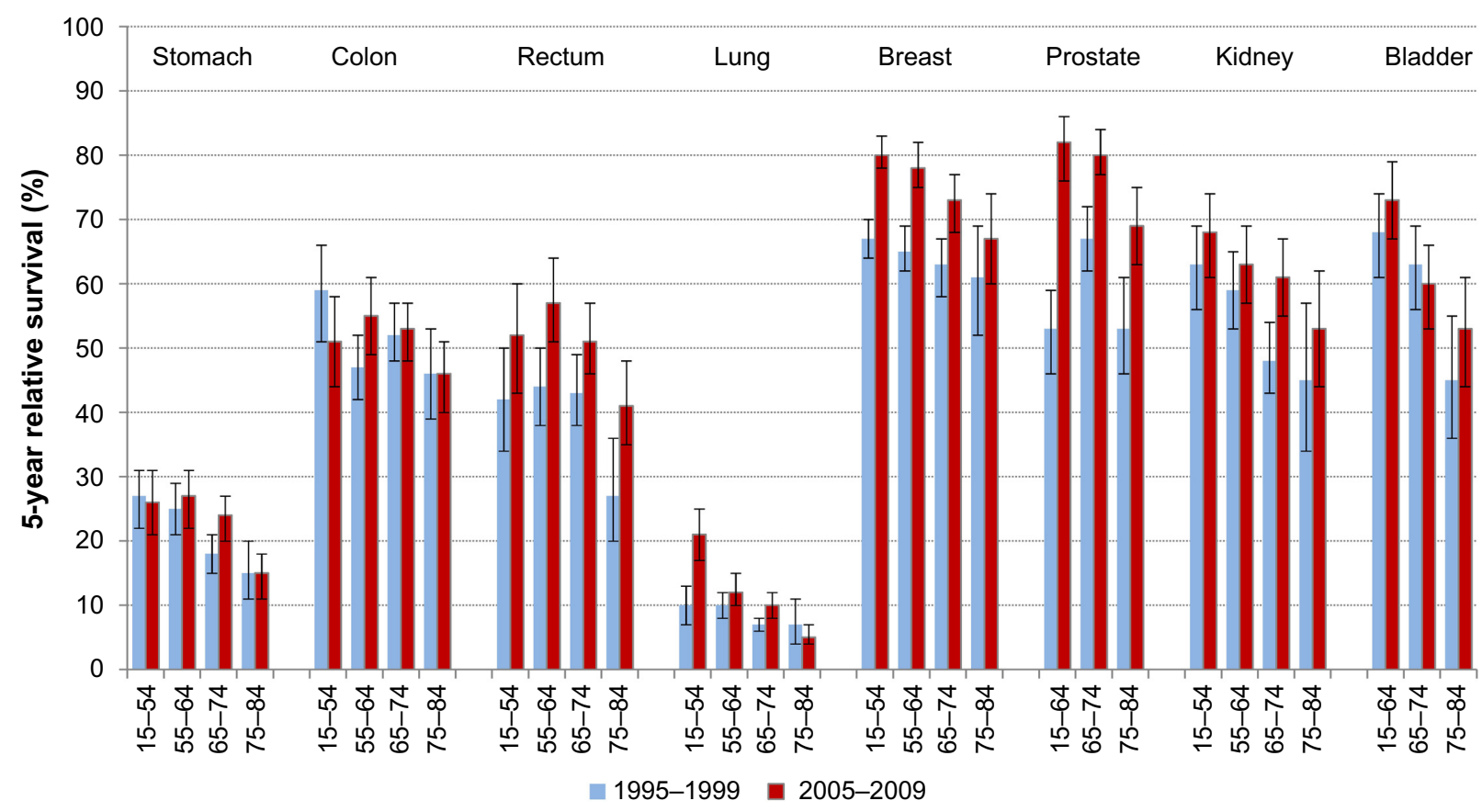

Figure I The 5-year relative survival ratios (\%) with 95\% confidence intervals by cancer site and age at diagnosis, Estonia 1995-1999 and 2005-2009. 
Table 5 Percentage of DCl cases eligible for survival analysis in 200I-2008 and the comparison of DCl-included ("true") and DClexcluded period estimates of 5-year relative survival ratios (\%) by age at diagnosis (years), 2005-2009

\begin{tabular}{|c|c|c|c|c|c|c|c|c|c|c|c|c|c|c|c|}
\hline \multirow[t]{2}{*}{ Cancer site } & \multicolumn{3}{|l|}{$\% \mathrm{DCl}$} & \multicolumn{3}{|c|}{ RSR DCI-included } & \multicolumn{3}{|c|}{ RSR DCl-excluded } & \multicolumn{3}{|c|}{ Difference (\% units) } & \multicolumn{3}{|c|}{$\%$ overestimation } \\
\hline & $\begin{array}{l}\text { I5-64 } \\
\text { years }\end{array}$ & $\begin{array}{l}65-74 \\
\text { years }\end{array}$ & $\begin{array}{l}75-84 \\
\text { years }\end{array}$ & $\begin{array}{l}15-64 \\
\text { years }\end{array}$ & $\begin{array}{l}65-74 \\
\text { years }\end{array}$ & $\begin{array}{l}75-84 \\
\text { years }\end{array}$ & $\begin{array}{l}15-64 \\
\text { years }\end{array}$ & $\begin{array}{l}65-74 \\
\text { years }\end{array}$ & $\begin{array}{l}75-84 \\
\text { years }\end{array}$ & $\begin{array}{l}15-64 \\
\text { years }\end{array}$ & $\begin{array}{l}65-74 \\
\text { years }\end{array}$ & $\begin{array}{l}75-84 \\
\text { years }\end{array}$ & $\begin{array}{l}15-64 \\
\text { years }\end{array}$ & $\begin{array}{l}65-74 \\
\text { years }\end{array}$ & $\begin{array}{l}75-84 \\
\text { years } \\
\end{array}$ \\
\hline Stomach & 2.1 & 3.5 & 5.0 & 26.4 & 23.7 & 14.5 & 27.1 & 25.1 & 16.1 & 0.7 & $\mathrm{I} .4$ & 1.6 & 2.7 & 5.9 & 11.0 \\
\hline Colon & 1.0 & 1.4 & 3.1 & 53.8 & 52.7 & 45.8 & 54.4 & 54.0 & 47.7 & 0.6 & 1.3 & 1.9 & I.I & 2.5 & 4.1 \\
\hline Rectum & 1.2 & 1.3 & 3.6 & 55.5 & 51.4 & 41.5 & 56.3 & 52.5 & 44.0 & 0.8 & 1.1 & 2.5 & 1.4 & 2.1 & 6.0 \\
\hline Lung & 3.6 & 5.1 & 8.8 & 14.8 & 9.8 & 5.2 & 15.7 & 10.9 & 6.2 & 0.9 & 1.1 & 1.0 & 6.1 & 11.2 & 19.2 \\
\hline Breast (female) & 0.4 & I.I & 0.8 & 79.6 & 72.8 & 67.2 & 80.0 & 73.9 & 68.1 & 0.4 & 1.1 & 0.9 & 0.5 & 1.5 & 1.3 \\
\hline Prostate & 0.7 & 2.0 & 3.7 & 81.8 & 80.4 & 68.9 & 82.4 & 82.2 & 72.2 & 0.6 & 1.8 & 3.3 & 0.7 & 2.2 & 4.8 \\
\hline Kidney & I.I & 2.1 & 3.8 & 65.3 & 61.2 & 53.0 & 66.2 & 62.7 & 55.9 & 0.9 & 1.5 & 2.9 & 1.4 & 2.5 & 5.5 \\
\hline Bladder & 0.8 & 1.6 & 2.9 & 73.5 & 59.8 & 52.7 & 73.7 & 61.2 & 55.0 & 0.2 & $\mathrm{I} .4$ & 2.3 & 0.3 & 2.3 & 4.4 \\
\hline
\end{tabular}

Abbreviations: $\mathrm{DCl}$, death certificate initiated; RSR, relative survival ratio.

of survival estimates. ${ }^{24}$ The effect of cases ascertained via death certificates on survival is site-specific: for rapidly lethal cancers, the proportion of such cases is higher. ${ }^{25,26}$ This was confirmed by a previous analysis of Estonian data that showed a $10 \%$ relative overestimation of relative survival estimates for lung and pancreatic cancer when comparing data sets with and without DCI cases, while the effect on cancers with better prognosis was much smaller. ${ }^{9}$ In this paper, we have looked at the age-specific effect of excluding DCI cases from survival analysis. This topic became relevant as a result of the temporary disruption of the routine practices of the ECR regarding case ascertainment via death certificates for the period 2001-2007. We have shown that the proportion of DCI cases is higher among the elderly, and consequently, the impact on relative survival is age-specific. The absolute effect was around $3 \%$ units for kidney and prostate cancer in the 75-84 years age group, while the relative effect was close to $20 \%$ for lung cancer in the same age group. Therefore, caution should be exercised when interpreting survival estimates for older patients based on cancer registry data that have been collected without additional case ascertainment via death certificates.

Cancer survival has been observed to be lower among elderly patients compared with their younger counterparts in EUROCARE studies. ${ }^{17,27}$ The comparison of elderly (70-84 years) and middle-aged (55-69 years) patients showed an increasing gap for most cancer sites through the $1990 \mathrm{~s}^{2}$ In the US, rises in 10-year survival were less pronounced among elderly patients, also leading to a persisting or widening age gradient. ${ }^{1}$

One of the possible explanations for age gradient in cancer survival is less favorable stage distribution among the elderly. In our study, we did not find a clear shift toward more advanced stages among patients aged 75-84 years. However, this may have been obscured by a larger propor- tion of cases with unknown stage in this age group. Less thorough diagnostic workup, as already discussed, may also lead to stage migration among older patients due to undetected regional or distant metastases. The observation that age gradient was larger at 1 year after diagnosis than at 5 years after diagnosis for digestive and lung cancers suggests a more advanced stage at diagnosis among the elderly, as was also hypothesized in the EUROCARE-3 based analysis. ${ }^{28}$

Another possible explanation for the age gradient is higher prevalence of comorbid conditions among the elderly. While it is widely recognized that people with comorbidities tend to receive suboptimal treatment, it is unclear whether it reflects less access to specialized care, patient preferences, treatment compliance, or higher risk of toxicity. ${ }^{29}$ Elderly patients are less likely to receive definitive therapies, associated with comorbidities or independently of those,,$^{19,30-32}$ and their chance of completing a course of cancer treatment is lower. ${ }^{29}$ There is lack of optimized treatment regimens for this age group due to the exclusion of elderly patients from clinical trials. ${ }^{33,34}$

In our study, we observed a widening age gradient for cancers of lung, breast, and prostate, as younger patients experienced much larger survival gain. For breast cancer, younger women have clearly benefited more from both earlier diagnosis and treatment advances in Estonia, as was shown in a previous analysis of stage-specific survival. ${ }^{3}$ At present, organized mammography screening in Estonia is limited to women aged 50-62 years. Earlier studies have observed inadequate clinical management of older breast cancer patients. ${ }^{35}$ Although there is no organized screening for prostate cancer in Estonia, the steeply rising trends in incidence and survival with no decreases in mortality ${ }^{9}$ suggest intensified prostate-specific antigen (PSA) testing. This notion is supported by the increase in the proportion of 
localized prostate cancers from $50 \%$ in $1995-1999$ to $66 \%$ in 2005-2008 (74\% in the 15-54 years age group, data not shown). Similar trends were seen in Denmark, another country without systematic screening. ${ }^{36}$ The doubling of the RSR for lung cancer among young patients without any favorable changes in the stage distribution (data not shown), suggests either treatment advances or changes in histological types that have been observed elsewhere. ${ }^{37}$

In conclusion, we were able to show, using real life data, that the exclusion of DCI cases from analysis introduced overestimation of relative survival estimates in the magnitude of up to $3 \%$ units among elderly patients, whilst the effect was smaller among younger patients. Cancer registry data quality, in terms of $\% \mathrm{MV}, \% \mathrm{DCI} / \% \mathrm{DCO}$, and proportion of unknown stage, decreased along with increasing age at diagnosis. This suggests that elderly patients in Estonia are less thoroughly investigated compared with younger patients and that there is room for improving outcomes among elderly patients via better clinical management. In general, young or middle-aged patients experienced larger survival gain from 1995-1999 to 2005-2009 than older patients. It remains to be investigated whether patients with comorbid conditions or otherwise frail patients are optimally treated and what the role of socio-economic factors and patient compliance are.

\section{Acknowledgments}

This work was supported by Estonian Research Council (grants number IUT5-1 and TARTH15017I) and European Regional Development Fund (Estonian Research Council, program TerVE, project EVRKA, contract number 2-14.3.1/13/8). The authors thank Dr Margit Mägi and Mrs Pille Härmaorg from the Estonian Cancer Registry for providing the data, and Mr Alex Baburin for technical help.

\section{Disclosure}

The authors report no conflicts of interest in this work.

\section{References}

1. Brenner H, Arndt V. Recent increase in cancer survival according to age: higher survival in all age groups, but widening age gradient. Cancer Causes Control. 2004;15(9):903-910.

2. Quaglia A, Tavilla A, Shack L, et al. The cancer survival gap between elderly and middle-aged patients in Europe is widening. Eur J Cancer. 2009;45(6):1006-1016.

3. Baburin A, Aareleid T, Padrik P, Valvere V, Innos K. Time trends in population-based breast cancer survival in Estonia: analysis by age and stage. Acta Oncol. 2014;53(2):226-234.

4. Capocaccia R, Gatta G, Roazzi P, et al. The EUROCARE-3 database: methodology of data collection, standardisation, quality control and statistical analysis. Ann Oncol. 2003;14(Suppl 5):v14-v27.
5. Brenner H, Hakulinen T. Implications of incomplete registration of deaths on long-term survival estimates from population-based cancer registries. Int J Cancer. 2009;125(2):432-437.

6. Adams J, Audisio RA, White M, Forman D. Age-related variations in progression of cancer at diagnosis and completeness of cancer registry data. Surg Oncol. 2004;13(4):175-179.

7. Rahu M. Estonia. In: Parkin DM, Muir CS, Whelan SL, Gao Y-T, Ferlay J, Powell J, editors. Cancer Incidence in Five Continents, Vol VII. Lyon, France: International Agency for Research on Cancer; 1997:569-573.

8. Rahu M, McKee M. Epidemiological research labelled as a violation of privacy: the case of Estonia. Int J Epidemiol. 2008;37(3):678-682.

9. Innos K, Baburin A, Aareleid T. Cancer patient survival in Estonia 1995-2009: time trends and data quality. Cancer Epidemiol. 2014(3);38: $253-258$.

10. Innos K, Rahu M, Rahu K. Feasibility of cohort studies in Estonia. Occup Environ Med. 1999;56(7):499-502.

11. Ederer F, Heise H. Instructions to IBM 650 Programmers in Processing Survival Computations. Methodological Note No 10. Bethesda, MD: End Results Evaluation Section, National Cancer Institute; 1959.

12. Brenner H, Gefeller O, Hakulinen T. Period analysis for 'up-to-date' cancer survival data: theory, empirical evaluation, computational realisation and applications. Eur J Cancer. 2004;40(3):326-335.

13. Brenner $H$, Rachet $B$. Hybrid analysis for up-to-date long-term survival rates in cancer registries with delayed recording of incident cases. Eur J Cancer. 2004;40(16):2494-2501.

14. Corazziari I, Quinn M, Capocaccia R. Standard cancer patient population for age standardising survival ratios. Eur J Cancer. 2004; 40(15):2307-2316.

15. Dickman PW, Coviello E, Hills M. Estimating and modelling relative survival. STATA J. 2015;15(1):186-215.

16. Gondos A, Holleczek B, Arndt V, Stegmaier C, Ziegler H, Brenner H. Trends in population-based cancer survival in Germany: to what extent does progress reach older patients? Ann Oncol. 2007;18(7):1253-1259.

17. De Angelis R, Sant M, Coleman MP, et al. Cancer survival in Europe 1999-2007 by country and age: results of EUROCARE-5 - a populationbased study. Lancet Oncol. 2014;15(1):23-34.

18. Gatta G, Capocaccia R, Sant M, et al. Understanding variations in survival for colorectal cancer in Europe: a EUROCARE high resolution study. Gut. 2000;47(4):533-538.

19. Lavelle K, Downing A, Thomas J, Lawrence G, Forman D, Oliver SE. Are lower rates of surgery amongst older women with breast cancer in the UK explained by co-morbidity? Br J Cancer. 2012;107(7):1175-1180.

20. Lavelle K, Todd C, Moran A, Howell A, Bundred N, Campbell M. Non-standard management of breast cancer increases with age in the $\mathrm{UK}$ : a population based cohort of women $\geq 65$ years. Br $J$ Cancer. 2007;96(8):1197-1203.

21. de Rijke JM, Schouten LJ, Schouten HC, Jager JJ, Koppejan AG, van den Brandt PA. Age-specific differences in the diagnostics and treatment of cancer patients aged 50 years and older in the province of Limburg, The Netherlands. Ann Oncol. 1996;7(7):677-685.

22. Audisio RA, Bozzetti F, Gennari R, et al. The surgical management of elderly cancer patients; recommendations of the SIOG surgical task force. Eur J Cancer. 2004;40(7):926-938.

23. Silcocks P. Survival of death certificate initiated registrations: selection bias, incomplete trace-back or higher mortality? Br J Cancer. 2006; 95(11):1576-1578.

24. Brenner H, Jansen L. Restriction to period of interest improves informative value of death certificate only proportions in period analysis of cancer survival. J Clin Epidemiol. Epub March 14, 2015.

25. Pollock AM, Vickers N. Why are a quarter of all cancer deaths in south-east England registered by death certificate only? Factors related to death certificate only registrations in the Thames Cancer Registry between 1987 and 1989. Br J Cancer. 1995;71(3):637-641.

26. Robinson D, Sankila R, Hakulinen T, Møller H. Interpreting international comparisons of cancer survival: the effects of incomplete registration and the presence of death certificate only cases on survival estimates. Eur J Cancer. 2007;43(5):909-913. 
27. Coleman MP, Gatta G, Verdecchia A, et al. EUROCARE-3 summary: cancer survival in Europe at the end of the 20th century. Ann Oncol. 2003;14(Suppl 5):v128-v149.

28. Vercelli M, Quaglia A, Casella C, et al. Relative survival in elderly cancer patients in Europe. EUROCARE Working Group. Eur J Cancer. 1998;34(14 Spec No):2264-2270.

29. Søgaard M, Thomsen RW, Bossen KS, Sørensen HT, Nørgaard M. The impact of comorbidity on cancer survival: a review. Clin Epidemiol. 2013;5(Suppl 1):3-29.

30. Lavelle K, Moran A, Howell A, Bundred N, Campbell M, Todd C. Older women with operable breast cancer are less likely to have surgery. $\mathrm{Br}$ J Surg. 2007;94(10):1209-1215.

31. Janssen-Heijnen ML, Houterman S, Lemmens VE, Louwman MW, Maas HA, Coebergh JW. Prognostic impact of increasing age and comorbidity in cancer patients: a population-based approach. Crit Rev Oncol Hematol. 2005;55(3):231-240.

32. Bouchardy C, Rapiti E, Fioretta G, et al. Undertreatment strongly decreases prognosis of breast cancer in elderly women. J Clin Oncol. 2003;21(19):3580-3587.
33. Lewis JH, Kilgore ML, Goldman DP, et al. Participation of patients 65 years of age or older in cancer clinical trials. J Clin Oncol. 2003; 21(7):1383-1389.

34. Elting LS, Cooksley C, Bekele BN, et al. Generalizability of cancer clinical trial results: prognostic differences between participants and nonparticipants. Cancer. 2006;106(11):2452-2458.

35. Sant M, Allemani C, Capocaccia R, et al. Stage at diagnosis is a key explanation of differences in breast cancer survival across Europe. Int J Cancer. 2003;106(3):416-422.

36. Outzen M, Brasso K, Martinussen N, et al. Prostate cancer in Denmark 1978-2009 - trends in incidence and mortality. Acta Oncol. 2013; 52(4):831-836.

37. Dillman RO, McClure SE. Steadily improving survival in lung cancer. Clin Lung Cancer. 2014;15(5):331-337.
Clinical Epidemiology

\section{Publish your work in this journal}

Clinical Epidemiology is an international, peer-reviewed, open access, online journal focusing on disease and drug epidemiology, identification of risk factors and screening procedures to develop optimal preventative initiatives and programs. Specific topics include: diagnosis, prognosis, treatment, screening, prevention, risk factor modification,

Submit your manuscript here: http://www.dovepress.com/clinical-epidemiology-journal

\section{Dovepress}

systematic reviews, risk \& safety of medical interventions, epidemiology \& biostatistical methods, and evaluation of guidelines, translationa medicine, health policies \& economic evaluations. The manuscript management system is completely online and includes a very quick and fair peer-review system, which is all easy to use. 